Silvio Košćak

\title{
Saint Jerome in Liber officialis of Amalar of Metz (775-850) and Rationale divinorum officiorum of William Durand (1230-1296)
}

\section{Sv. Hieronim v delu Liber officialis Amalarja iz Metza (775-850) in v spisu Rationale divinorum officiorum Vilijema Duranda (1230-1296)}

Abstract. Amalur of Metz and William Durand were medieval liturgists from the beginning and end of a long period during which liturgical treatises were created and labelled expositio missae or liturgical expositions. In the early $9^{\text {th }}$ century, Amaral of Metz compiled the exposition De ecclesiastico officio, in which he examines liturgical celebrations by using an allegorical interpretation and the contribution to the Carolingian reform. He eventually became a role model for later authors who created more or less similar treatises following his example. One author who considered Amaral a role model was William Durand the Elder, bishop of Mende in France. In the $13^{\text {th }}$ century, he compiled the exposition Rationale divinorum officiorum. Both expositions were very influential not only in the period in which they were created but also in later periods. Amalar's exposition enhanced the development of allegorical interpretations in the Middle Ages, while Durand's exposition has been used up to the liturgical reform introduced by the Second Vatican Council. In the present paper, the author explores the reception of Saint Jerome by both authors referred to above. The said authors do not use the patristic ideas in their original sense; they do not expand on them theologically. Their purpose for using patristic sources is to verify doctrines or liturgical practices of their period. Introducing allegory in the interpretation of liturgy and compiling existing material is relevant for transmitting the Fathers' beliefs to future generations.

Keywords: liturgical exposition, Jerome, reception, Rationale divinorum officiorum, De ecclesiastico officio

Povqetek: Amalar iz Metza in Viljem Durand, srednjeveška liturgika, sodita na začetek in konec dolgega obdobja, ko so se oblikovale liturgične razprave z razlago obreda svete maše (expositio missae). V začetku 9. stoletja je Amalar sestavil 
delo De ecclesiastico officio, v katerem z alegorično interpretacijo razlaga bogoslužje v odnosu do karolinške reforme. Sčasoma je postal vzor še za poznejše razlagalce, med drugim tudi za Viljema Duranda, škofa francoskega mesta Mende, ki je v 13. stoletju pripravil Rationale divinorum officiorum. Oba spisa sta imela velik vpliv ne le v obdobjih nastanka, marveč tudi pozneje. Amalarjevo delo je okrepilo razvoj alegorične interpretacije v srednjem veku, Viljemovo pa je ostalo v rabi vse do liturgične reforme drugega vatikanskega koncila. V prispevku avtor obravnava recepcijo sv. Hieronima v navedenih delih. Avtorja se ne sklicujeta na patristično misel na izviren način, v smislu razvoja teološke misli, marveč z uporabo patrističnih virov utemeljujeta nauk in bogoslužne prakse svojega časa. Alegorija kot pomoč pri razlagi liturgije in za zbiranje že obstoječih besedil sta metodi za prenos učenja očetov na prihodnje generacije.

Kljurne besede: razlaga liturgije, Hieronim, recepcija, Rationale divinorum officiorum, De ecclesiastico officio

\section{Amalar of Metz and William Durand in the Context of Medieval Theology}

Medievalists and theologists who explore medieval theology have recently been writing about the significance of medieval liturgists (Košćak 2019, 23-25). When it comes to liturgy, medieval theology abounds in authors who can testify about the context in which they created their works. Two authors referred to in the title of the present paper, Amalar of Metz (Amalarius Metensis, abbr. Amalar.) and William Durand (Guillaume Durand, abbr. Guil. Dur.), primarily discuss the symbolism inscribed within the medieval course of liturgical celebrations. The authors also discuss the literary creativity of the period, primarily the role models used in the creation of their original works.

Amalar of Metz, who introduced the allegorical method into the interpretation of liturgical celebration during the Carolingian era, was born in the late $8^{\text {th }}$ century in Burgundy. He was appointed the Archbishop of Trier around 809. He started writing his well-known liturgical works around 813. Following Charlemagne's death, he was demoted from the position of bishop. He was back in the king's good graces in 825. In 835, he was assigned the position of the Archbishop of Lyon. He spent his whole life discovering the symbolism in liturgical celebrations (Knibbs 2014, vii-xxx). He is the first author in the long line of writers of the medieval literary form entitled liturgical exposition. ${ }^{1}$ This literary form reached its pinnacle in the works of William Durand the Elder. Works of authors who succeeded him were much less successful, while Durand himself remained an authority up to the Second Vatican Council.

Liturgical exposition is a medieval literary form used by liturgists of the period to teach the clergy on the symbolism of liturgical celebrations and everything related to it (church architecture, gestures, liturgy times, sacraments, church services in liturgy etc.). 
William Durand was born in 1230 or 1231 in the French town of Puymission near Béziers. He held various positions and honours in the French church hierarchy. He was named a clergyman in Miquelon in 1251, while in 1254, he became the spiritual leader of a church in Narbonne. From 1255, he studied canonical law at Modena. During the pontificate of Pope Clement IV (1256-1268), he was appointed priest of the Roman Curia. He was named the general auditor at the Holy See court of appeals (audientia causarum sacri palatii). He also held the position of captain and prefect of the Papal State. In 1285, he was appointed bishop of the French town of Mende. In 1295, Pope Bonifacius VIII offered him the Ravenna Diocese. However, Durand declined this position. He died on 1 November 1926. The epitaph on his grave in the Roman basilica Santa Maria sopra Minerva testifies his significance in the Church ranks and the significance of his works. (Košćak 2019, 25-26)

\section{The Use of Patristic Ideas in Liturgical Expositions by Amalar of Metz and William Durand the Elder}

The present paper explores the reception of Saint Jerome's ideas by both authors mentioned in the title. Medieval authors do not use the patristic ideas in their original sense; in other words, they do not expand on the Fathers' ideas in a theological sense. The goal of using patristic sources is to verify the teachings or liturgical practices of the recent period. Compilatory methods of the subject authors are used to transmit the Fathers' ideas to following periods, but a touch of originality characteristic of the context under research is also evident.

Amalar's best-known work, Liber officialis or De ecclesiastico officio (On the Liturgy), is the subject of research. ${ }^{2}$ This work reached a broad medieval audience. Jean-Michel Hanssens discovered seventy-four manuscripts in circulation throughout the centuries (Knibbs 2014, xi), while the manuscript underwent three redactions (xv-xvi).

In the work's Prologue, Amalar introduces the testimony on the reasons behind his writing, which are, in his words, "desiderio ut scirem rationem aliquam de ordine nostrae Missae« (Knibbs 2014, 18-19). He writes that his comment would present »necnon etiam et iterare quod a scripto sancti Ambrosii et sancti Augustini didici de ordine orationum in Missa et in aliis officiis « $(2014,2)$. Even though he claims that he would be transmitting the ideas of the most prominent patristic authors from the Middle Ages, he uses other sources of the Church fathers. For this reason, in the primary stage of the research, we created a list of all citations of the patristic works within Liber officialis. When it comes to the other patristic sources, as well as those of his contemporaries, he cites the works of Saint Jerome, Saint Bede the Venerable, Saint Cyprian, Saint Gregory the Great, Saint Gregory

For the critical edition of Amalar's works, see Hanssens 1948-1950. It is published in three volumes: Tomus I - Introductio, Opera minora; Tomus II - Liber officialis; Tomus III - Liber de ordine antiphonarii, Eclogae de ordine romano; Appendix Tomi I et II - Indices. 
of Nazianzus, Saint Ignatius of Antioch, Saint John Chrysostom, Rabanus Maurus, Saint Isidore of Seville, Boetius and Gregory of Tours.

Considering the initial thought on Saint Augustine and Saint Ambrose and with the preliminary research into the presence of citations of the Fathers unveiling many citations by Saint Jerome, two research questions were asked in the context of our research: 1 . What is the reason behind Amalar's use of Saint Jerome's ideas? 2. Does Amalar of Metz use Saint Jerome's works to base a new method for interpreting liturgy on the Fathers' foundations?

We researched the reception of Saint Jerome in Rationale divinorum officiorum by William Durand the Elder, in an equal manner (Košćak 2019, 26-28). At the very end of Rationale divinorum officiorum Durand acknowledges that they used various sources for assembling the treatise (Thibodeau 2007, xx).

\subsection{The Reception of Saint Jerome in Liber officialis by Amalar of Metz}

Below we provide a list of all sections where Amalar of Metz cited Saint Jerome. After the title of the cited work, numbers within slashes provide information on the citation location in Saint Jerome's work. The reference to Saint Jerome's work is followed by the location of the citation in Amalar's work. Saint Jerome was cited in sixty-five places throughout four books of Liber officialis (Lib. off.). Amalar references various works by Saint Jerome, mostly his Commentaries on the Scripture.

Of Saint Jerome's commentaries on the Books of the Old Testament, the most cited is the Hier., In Is., which was cited in nine places (In Is.14.53 - Lib. off. 1.11.8; In Is. 17.63 - Lib. off. 1.11.11; In Is. 17.61 - Lib. off. 1.12.45; In Is. 3.7 - Lib. off. 1.12.47; In Is. 2 - Lib. off. 1.19.7-8; In Is. 15 - Lib. off. 1.19.12; In Is. 1.1 - Lib. off. 3.3.6; In Is. 4.11 - Lib. off. 4.12.6; In Is. 4.12 - Lib. off. 4.12.7). The other Old Testament-related commentaries Amalar cites are the In Zach. (In Zach. 1.1 - Lib. off. 1.1.7-8), In loel (In loel 2 - Lib. off. 1.2.2; 3.1.3), In Ezech. (In Ezech. 11.36 - Lib. off. 1.8.6; In Ezech. 13.44 - Lib. off. 1.16.5; In Ezech. 3.9 - Lib. off. 3.5.2), In Hab. (In Hab. 2 - Lib. off. 2.13.4; In Hab. 2.3 - Lib. off. 4.16.2), In Hos. (In Hos. 2 - Lib. off. 1.13.8) and In Dan. (In Dan. 6 - Lib. off. 4.3.1; In Dan. 12 - Lib. off. 4.10.13).

Of Saint Jerome's commentaries to the Books of the New Testament, Amalar uses the In Matth. (In Matth. 4 - Lib. off. 1.16.3; In Matth. 1.9 - Lib. off. 1.36.6-7; In Matth. 2.2 - Lib. off. 2.20.1; In Matth. 6.26 - Lib. off. 3.23.14; In Matth. 4.26 Lib. off. 3.23.25), In Tit. (In Tit. 1 - Lib. off. 2.3.2-4; In Tit. 1 - Lib. off. 2.13.4-6), In Eph. (In Eph. 3.5 - Lib. off. 1.1.21; 3.2.12; 4.3.15-16; In Eph. 2 - Lib. off. 1.14.4; In Eph. 2.4 - Lib. off. 1.27.27; In Eph. 3.6 - Lib. off. 3.4.4) and In Gal. (In Gal. In Gal. 2.4 - Lib. off. 4.37.2-5).

Of the other texts written by Saint Jerome, Amalar cites his Epistles (Epistulae), more specifically Ep. 78 (Ep. 78.2 - Lib. off. 1.4.5; 1.18.2-3), Ep. 77 (Ep. $77.4-$ Lib. off. 1.12.40), Ep. 108 (Ep. 108.9 - Lib. off. 1.14.7; Ep. 108.19 - Lib. off. 4.9.20), Ep. 41 (Ep. 41.3 - Lib. off. 1.36.4; 1.37.10), Ep. 71 (Ep. 71.6 - Lib. off. 1.36,5), Ep. 52 (Ep. 52.5 - Lib. off. 2.4.1-2), Ep. 146 (Ep. 146.2 - Lib. off. 2.12.7; Ep. 146.1 - Lib. off. 2.13.11; 2.13.15) and Ep. 64 (Ep. 64.20 - Lib. off. 2.15.2; Ep. 64.2 - Lib. off. 


\subsection{1; Ep. 64.21 - Lib. off. 2.22.1). Below we provide some of the citations of} Saint Jerome's texts referred to above.

\begin{tabular}{|c|c|}
\hline $\begin{array}{l}\text { Hier., In Is. } 14.53 \\
\text { Amalar., Lib. off. } 1.11 .8\end{array}$ & $\begin{array}{l}\text { „Si posuerit pro peccato animam suam - ille quem Dominus conterere } \\
\text { voluit sive mundare - videbit semen longevum quod seminavit in bona } \\
\text { terra. De quo et in Evangelio scriptum est: Exiit qui seminat seminare se- } \\
\text { men bonum." }\end{array}$ \\
\hline $\begin{array}{l}\text { Hier., In Ezech. } 11.36 \\
\text { Amalar., Lib. off. } 1.8 .6\end{array}$ & $\begin{array}{l}\text { „Creator enim omnium sum; peperci eis et sanctificavi illos et gloriae pris- } \\
\text { tinae restitui, ita ut super credentes et ab errore conversos effunderem } \\
\text { aquam mundam baptismi salutaris, et mundarem eos ab abominationi- } \\
\text { bus suis et ab universis erroribus quibus fuerant occupati, et darem eis } \\
\text { cor novum, ut crederent in Filium Dei. « }\end{array}$ \\
\hline $\begin{array}{l}\text { Hier., In Dan. } 6 \\
\text { Amalar., Lib. off. } 4.3 .1\end{array}$ & $\begin{array}{l}\text { „Tria autem tempora quibus Deo flectenda sunt genua: tertiam horam et } \\
\text { sextam et nonam, ecclesiastica traditio intelligit. Denique tertia hora des- } \\
\text { cendit super apostolos Spiritus Sanctus; sexta volens Petrus comedere, ad } \\
\text { orationem ascendit in caenaculum; nona Petrus et lohannes pergebant } \\
\text { ad templum." }\end{array}$ \\
\hline $\begin{array}{l}\text { Hier., In Matth. } 4 \\
\text { Amalar., Lib. off. } 1.16 .3\end{array}$ & $\begin{array}{l}\text { »Traditio ludeaorum est Christum in media nocte venturum in similitu- } \\
\text { dine Aegyptii temporis. Quando Pascha caelebratum est, exterminator } \\
\text { venit et Dominus super tabernacula transiit, et sanguine agni postes nos- } \\
\text { trarum frontium consecrati sunt. Unde reor et traditionem apostolicam } \\
\text { permansisse, ut die vigiliarum Paschae ante noctis dimidium populos di- } \\
\text { mittere non liceat, expectantes adventum Christi, et, postquam illud tem- } \\
\text { pus transierit, securitate praesumpta, festum cuncti agunt diem." }\end{array}$ \\
\hline $\begin{array}{l}\text { Hier., In Eph. } 3.5 \\
\text { Amalar., Lib. off. 1.1.21 }\end{array}$ & $\begin{array}{l}\text { "Significare absconditam cogitationem, cum inflammatur sensus noster } \\
\text { ad libidinem, et carnis titillationibus anima ignita succenditur; et nihilomi- } \\
\text { nus Dei timore et mentis iudicio refrenatur." }\end{array}$ \\
\hline $\begin{array}{l}\text { Hier., In Gal. } 2.4 \\
\text { Amalar., Lib. off. 4.37.2-5 }\end{array}$ & $\begin{array}{l}\text { „Si dies observare non licet, et menses, et tempora, et annos, nos quoque } \\
\text { similiter crimen incurrimus, quartam sabbati observantes et Parasceven } \\
\text { et diem Dominicam et ieiunium Quadragesimae et Paschae festivitatem } \\
\text { et Pentecostes laetitiam et, pro varietatem regionum, diversa in honore } \\
\text { martyrum tempora constituta... Nos enim non azymorum pascha celebra- } \\
\text { mus, sed resurrectionis et crucis. Nec septem iuxta morem Israel numera- } \\
\text { mus ebdomadas in Pentecoste; sed Spiritus Sancti veneramur adventum. } \\
\text { Et ne inordinate congregati populi fides minueretur in Christo, propterea } \\
\text { dies aliqui constituti sunt, ut in unum omnes pariter veniremus - non } \\
\text { quod celebrior sit dies illa qua convenimus, sed quacumque die conve- } \\
\text { niendum sit, ex conspectu mutuo laetitia maior oriatur." }\end{array}$ \\
\hline $\begin{array}{l}\text { Hier., Ep. } 78.2 \\
\text { Amalar., Lib. off. } 1.4 .5\end{array}$ & $\begin{array}{l}\text { „Nec mirum si in illo numeri sacramento perveniamus ad regna caelo- } \\
\text { rum, sub quo Dominus atque salvator a primo patriarcha pervenit ad vir- } \\
\text { ginem - quasi ad lordanem, qui pleno gurgite fluens, Spiritus Sancti gratiis } \\
\text { redundabat." }\end{array}$ \\
\hline $\begin{array}{l}\text { Hier., Ep. } 41.3 \\
\text { Amalar., Lib. off. } 1.36 .4\end{array}$ & $\begin{array}{l}\text { „Nos unam Quadragesimam secundum traditionem apostolorum tempo- } \\
\text { re nobis orbe congruo ieiunamus; illi tres in anno faciunt quadragesimas, } \\
\text { quasi tres passi sint salvatores. Non quod et per totum annum, excepta } \\
\text { Pentecoste, ieiunare non liceat, sed quod aliud sit necessitate, aliud vol- } \\
\text { untate munus offerre." }\end{array}$ \\
\hline $\begin{array}{l}\text { Hier., Ep. } 64.20 \\
\text { Amalar., Lib. off. } 2.15 .2\end{array}$ & $\begin{array}{l}\text { "Legimus in Levitico iuxta praeceptum Dei Moysen lavisse Aaron et filios } \\
\text { eius. lam tunc purgationem mundi et rerum omnium sanctitatem bap- } \\
\text { tismi sacramenta signabant. Non accipiunt vestes nisi loti prius sordibus, } \\
\text { nec ornantur ad sacra nisi in Christo novi homines renascantur." }\end{array}$ \\
\hline
\end{tabular}

Table 1: $\quad$ The selected quotations of St. Jerome (part 1).

It has already been said that Amalar's originality lies in the use of the allegorical method of interpretation. The existing works claim that »the allegorical significance of liturgical words and actions reflects, for Amalar, the divine inspiration of those who devised the liturgy« (Knibbs 2014, xviii). However, based on the citations 
used that interpret the Scripture in an allegorical manner, we can say that liturgy for Amalar has allegorical meanings in the same manner as the Scripture does.

Many of Amalar's interpretations and the selected citations of the Fathers' work may seem arbitrary. However, the amount of Jerome's citations used in which he interprets lines from the Scripture in an allegorical manner provides the answer to why Amalar specifically uses those interpretations and why he uses Jerome's interpretations. Jerome used the allegorical method in the interpretation of the Scripture. On the other hand, Amalar used allegory for interpreting liturgy to prove that the ,architects' of liturgical celebrations are equal to the writers of the Scripture books. Just like Scripture writers were guided by divine inspiration, the same applied to those who modelled liturgy. Hence, it is no surprise that he used the Fathers' texts drafted as commentaries on the Old Testament for verifying the allegorical interpretation of individual liturgical celebrations. This is also the reason why he often cites texts written by Saint Jerome.

Of all the Fathers' texts, Saint Jerome is the most represented author in the Liber officialis corpus. Contemporary authors claim that Saint Jerome's theological insights are not as deep as Saint Augustine's (Bratulić 2018, 221-222). The fame he acquired by translating the Holy Bible and writing his commentaries has not diminished even after the ecclesiastical and political changes of the Middle Ages until Amalar's period. In Liber officialis, he is not dependent on Jerome's interpretations. Jerome's citations conveyed in Liber officialis demonstrate that Amalar based his allegorical method specifically on Jerome's allegorical interpretation of the Scripture.

It should also be added that Saint Augustine's theology is far more represented in Liber officialis than that of Saint Jerome. The explored citations of Saint Augustine demonstrate that Amalar used texts that are theologically more developed. As stated by Amalar himself, Augustine's theology is his teacher, and he wants it to be transferred to the priests. Our exploration of the reception of Saint Jerome by Amalar of Metz leads us to the conclusion that he inherited theological insights from Saint Augustine and new methodologies for interpreting liturgy from Saint Jerome.

\subsection{The Reception of Saint Jerome by William Durand}

Our research also includes the reception of Saint Jerome by William Durand during his most productive period of writing liturgical expositions. He is Amalar's late medieval successor. Even though he is not the last ever compiler of liturgical exposition, he is the most successful one - the quality of texts decreased after his demise. The number of later editions of Durand's exposition Rationale divinorum officiorum (Rat. div.) shows the relevance of this work in later periods. In addition, Durand's exposition is the second-ever printed book.

Our recent research was conducted to write the doctoral thesis on Rationale divinorum officiorum by William Durand (1230-1296) as an example of medieval pre-treatise ecclesiology. It unveiled a large number of patristic texts that Durand used for creating his expositions. Even a superficial analysis shows that he is en- 
tirely dependent on his literary role models. In other words, the process of creating his exposition primarily consisted of compiling sources. Since the author was an expert in canon law, the majority of sources included medieval legal literature. Concerning methodology, the structure of the work, liturgical topics included or interpretation of liturgy, Durand is entirely dependent on previous authors of expositions based on the Fathers' sources, beginning from Amalar of Metz to Pope Innocent III and Johannes Beleth (Thibodeau and Davril 2000, 229-247 [Apparatus in margine]; 248-269 [Apparatus fontium]).

Unlike Amalar's methodological originality, Durand is entirely dependent on his predecessors. Both authors studied in this paper attempt to penetrate the symbolism of liturgical celebration to educate the clergy of their times. The $13^{\text {th }}$-century clergy Durand addresses the people who were mainly uneducated about the meaning of celebrations. However, Timoty Thibodeau considers the compilation method as Durand's original contribution (1992). Of all the Fathers' texts used by Durand, no author stands out in terms of quantity. All authors have been used relatively equally to present his conclusions as accurate.

In our exploration of Durand's use of the Fathers' theology, Saint Jerome's in particular, we found citations used about the Church symbolism. In other words, Durand is a compiler of liturgical exposition and the creator of pre-treatise ecclesiology incorporated into the liturgical treatise (Holmes 2011). As stated in the literature, before the publication of the Bull by Pope Bonifacius VIII Unam sanctam in 1302, Durand reflected on the Church in the context of sacrament life, worship within the sacred space.

Here we present the works of Saint Jerome that have ecclesiological implications in Durand's exposition. These elements bear the same implications in its original context. Durand's Rationale divinorum officiorum contains fifteen such citations. The majority of these citations have been incorporated into larger units of canonical-legal literature used by Durand. This conclusion is brought forward by Timothy Thibodeau and Anselm Davril, editors of the critical edition of our reference source. The cited sections are presented in the same manner as for Amalar of Metz.

It can be concluded that Durand uses Saint Jerome's texts of the commentaries to the Scripture in order to verify his statements on the Church or to talk about ecclesiological topics to his contemporaries by using the patristic arguments. The sources include: In Am. (In Am. 2.4 - Rat. div. Pr. 9), In Mich. (In Mich. 1.2 - Rat. div. 1.1.22), In Is. (In Is. 3.2 - Rat. div. 2.10.5), In Ezech. (In Ezech. 13.44.20-Rat. div. 3.1.1), In Dan. (In Dan. 2.6.10 - Rat. div. 5.1.7), In Eph. (In Eph. 3.5.9 - Rat. div. 2.2.3) and In Tit. (In Tit. 1 - Rat. div. 2.11.16). In the ecclesiological context, he also uses Saint Jerome's work Liber interpretationis hebraicorum nominum (Nom. hebr. - Rat. div. 1.5.11; 1.1.4; 5.4.23). Other texts used by Durand in the context of speaking on the Church are Saint Jerome's Epistula Ad Rusticum monachum (Ep. 125.11 - Rat. div. 1.9.17; Ep.125.19 - Rat. div. 2.1.29), Ad Euangelum presbyterum (Ep. 156 - Rat. div. 2.10.5), Ad Nepotianum (Ep. 52.5 - Rat. div. 2.1.30) 
and Adversus lovinianum (Adv. lovin. 1.4-Rat. div. 1.5.11). Below we present the citations of Saint Jerome's texts referred to above.

\begin{tabular}{|c|c|}
\hline $\begin{array}{l}\text { Hier., In Am. } 2.4 \\
\text { Guil. Dur., Rat. div. Pr. } 9\end{array}$ & $\begin{array}{l}\text { »debemus divinam scripturam in ethica scrutari: primo iuxta litteram; se- } \\
\text { cundo iuxta allegoriam, id est spiritualem intelligentiam; tertio secundum } \\
\text { futurorum beatitudinem. « }\end{array}$ \\
\hline $\begin{array}{l}\text { Hier., Ep. } 125.11 \\
\text { Guil. Dur., Rat. div. 1.9.17 }\end{array}$ & "Semper aliquid operis facito, ut dyabolus inveniat te occupatum." \\
\hline $\begin{array}{l}\text { Hier., Adv. lovin. } 1.44 \\
\text { Guil. Dur., Rat. div. } 1.5 .11\end{array}$ & $\begin{array}{l}\text { „tres patriarche sepulti sunt in civitate Ebron in spelunca duplici cum tribus } \\
\text { uxoribus suis." }\end{array}$ \\
\hline $\begin{array}{l}\text { Hier., In Mich. } 1.2 \\
\text { Guil. Dur., Rat. div. } 1.1 .22\end{array}$ & "Vae dormientibus, exsurge qui dormis" \\
\hline $\begin{array}{l}\text { Hier., Quaest. hebr. in Gen. } \\
\text { Guil. Dur., Rat. div. 1.5.11 }\end{array}$ & $\begin{array}{l}\text { „tres patriarche sepulti sunt in civitate Ebron in spelunca duplici cum tribus } \\
\text { uxoribus suis." }\end{array}$ \\
\hline $\begin{array}{l}\text { Hier., Nom. hebr. Litt. } 1 \\
\text { Guil. Dur., Rat. div. 1.1.4 }\end{array}$ & "lerusalem vocatur, nam lerusalem visio pacis interpretatur." \\
\hline $\begin{array}{l}\text { Hier., Ep. } 156 \\
\text { Guil. Dur., Rat. div. } 2.10 .5\end{array}$ & „Presbyter ergo /.../ nomen est aetatis, episcopus vero dignitatis." \\
\hline $\begin{array}{l}\text { Hier., Ep. } 52.5 \\
\text { Guil. Dur., Rat. div. } 2.1 .30\end{array}$ & $\begin{array}{l}\text { "sunt reges et sacerdotes, id est regales sacerdotes; et sunt reges, id est, se } \\
\text { et alios in virtutibus regentes, et ita in Deo regnum habent." }\end{array}$ \\
\hline $\begin{array}{l}\text { Hier., Ep. } 125.19 \\
\text { Guil. Dur., Rat. div. } 2.1 .29\end{array}$ & "veritas angulos non amat" \\
\hline $\begin{array}{l}\text { Hier., In Is. } 2.3 .2 \\
\text { Guil. Dur., Rat. div. } 2.10 .5\end{array}$ & "Canities hominum prudentia est." \\
\hline $\begin{array}{l}\text { Hier., In Eph. 3.5.19 } \\
\text { Guil. Dur., Rat. div. 2.2.3 }\end{array}$ & $\begin{array}{l}\text { "Audiant, inquit, adulescentuli, audiant hii quibus officium est in ecclesia } \\
\text { psallendi, Deo non voce tantum sed corde esse cantandum, nec in tragedo- } \\
\text { rum modum guttur et fauces medicamine liniende sunt ut in ecclesia thea- } \\
\text { trales moduli et cantica audiantur." }\end{array}$ \\
\hline $\begin{array}{l}\text { Hier., In Ezech. } 13.44 .20 \\
\text { Guil. Dur., Rat. div. 3.1.1 } \\
\end{array}$ & $\begin{array}{l}\text { „Religio divina alterum habitum in ecclesiasticis officiis, alium in communi } \\
\text { usu.» }\end{array}$ \\
\hline $\begin{array}{l}\text { Hier., In Dan. 2.6.10 } \\
\text { Guil. Dur., Rat. div. 5.1.7 }\end{array}$ & $\begin{array}{l}\text { "Hinc habet ecclesiastica traditio quod ter in die genua sunt flectenda, scili- } \\
\text { cet in tertia, sexta et nona." }\end{array}$ \\
\hline $\begin{array}{l}\text { Hier., Nom. hebr. Litt. S } \\
\text { Guil. Dur., Rat. div. 5.4.23 }\end{array}$ & "Syon interpretatur speculatio sive contemplatio." \\
\hline
\end{tabular}

Table 2: $\quad$ The selected quotations of St. Jerome (part 2).

\section{Conclusion}

The use of the Fathers' theology in the Middle Ages is not only a verification of the rigid attitudes of the Church but is also used to develop original theological methods. Amalar of Metz founded the allegorical method for interpreting liturgy on Saint Jerome's allegorical interpretation of the Scripture. Throughout medieval times, liturgical expositions were written using this method, thereby transmitting the Fathers' ideas to future periods. William Durand achieved in transmitting the Fathers' ideas. He managed to transmit a wide variety of the Fathers' works by using the allegorical method and successfully compiling sources. A particular value of Durand's liturgical exposition lies in his integration of ecclesiological topics, whereby he defines the ecclesiological treatise form before the arrival of the original de ecclesia treatises. Regardless of their frequent allegorical simplification to 
find a deeper meaning behind liturgical celebrations, both authors influenced the comprehension of liturgy up to the last liturgical reform in the mid-20 $0^{\text {th }}$ century.

Both authors can be labelled teachers of what had then been a largely undereducated clergy. Their most outstanding contribution is the transmission of patristic ideas on liturgy to the Middle Ages. Amalar of Metz builds his allegorical method on the interpretation method used in the Fathers' period. Using the allegorical method for interpreting liturgy, Church jurist William Durand is original in using existing theological material. The majority of his sources of patristic theology are legal texts. His creation of the unique medieval liturgical treatise Rationale divinorum officiorum makes him a compiler of legal literature.

\section{Abbreviation}

CCCM - Corpus Christianorum Continuatio Mediaevalis.

\section{References}

Primary sources

Davril, Anselm and Timothy Thibodeau, eds. 1995-2000. Guillelmi Duranti Rationale divinorum officiorum. 3 vols. CCCM 140, 140A, 140B. Turnhaut: Brepols.

Hanssens, Jean Michel, ed. 1948-1950. Amalarii Episcopi Opera liturgica omnia. Studi e testi 138140. Vatican: Biblioteca Apostolica Vaticana.

\section{Secondary sources}

Bratulić, Josip. 2018. Svetost i čovječnost: $R a-$ sprave o hrvatskoj hagiografiji [Holiness and humanity: Discussions on hagiography]. Split: Književni krug.

Holmes, Stephan. 2011. William Durandus and a New Approach to the History of Ecclesiology. Ecclesiology 7:29-49.

Knibbs, Eric, ed. 2014. On the Liturgy: Amalar of Metz. Vol. 1. Cambridge; London: Harvard University Press.
Košćak, Silvio. 2019. Teološko-alegorijsko tumačenje noćne službe oficija u liturgijskoj ekspoziciji Vilima Duranda (1230. - 1296.) s naglaskom na antifone i psalmodiju [Theological-allegorial interpretation of the Holy Office nocturnal service in William Durand's liturgical exposition (1230-1296) with a focus on antiphones and psalmody]. Slovo: časopis Staroslavenskoga instituta u Zagrebu 70, no. 1:23-46.

Thibodeau, Timothy. 1992. William Durand: »Compilator Rationalis«. Ecclesia Orans 9:97113.

- - - 2007. The Rationale divinorum officiorum of William Durand of Mende. New York: Columbia University Press. 